LHT

39,2

\section{2}

Received 23 February 2020 Revised 25 February 2020 Accepted 25 February 2020

\title{
Intelligent libraries: a review on expert systems, artificial intelligence, and robot
}

\author{
Asefeh Asemi \\ Doctoral School of Business Informatics, Corvinus University of Budapest, \\ Budapest, Hungary and \\ University of Isfahan, Isfahan, Iran \\ Andrea Ko \\ Corvinus University of Budapest, Budapest, Hungary, and \\ Mohsen Nowkarizi \\ Department of Knowledge and Information Science, Ferdowsi University of Mashhad, \\ Mashhad, Iran
}

\begin{abstract}
Purpose - This paper reviews literature on the application of intelligent systems in the libraries with a special issue on the ES/AI and Robot. Also, it introduces the potential of libraries to use intelligent systems, especially ES/AI and robots.

Design/methodology/approach - Descriptive and content review methods are applied, and the researchers critically reviewed the articles related to library ESs and robots from Web of Science as a general database and Emerald as a specific database in library and information science from 2007-2017. Four scopes considered to classify the articles as technology, service, user and resource. It is found that published researches on the intelligent systems have contributed to many librarian purposes like library technical services like the organization of information resources, storage and retrieval of information resources, library public services as reference services, information desk and other purposes.

Findings - A review of the previous studies shows that ESs are a useable intelligent system in library and information science that mimic librarian expert's behaviors to support decision making and management. Also, it is shown that the current information systems have a high potential to be improved by integration with AI technologies. In this researches, librarian robots mostly designed for detection and replacing books on the shelf. Improving the technology of gripping, localizing and human-robot interaction are the main concern in recent librarian robot research. Our conclusion is that we need to develop research in the area of smart resources.

Originality/value - This study has a new approach to the literature review in this area. We compared the published papers in the field of ES/AI and robot and library from two databases, general and specific.
\end{abstract}

Keywords Library system, Intelligent systems, Artificial Intelligent (AI), Intelligent library, Smart library, Expert System (ES), Robot

Paper type Literature review

\section{Introduction}

In computer science, artificial intelligence (AI) is an important topic. In this context, the focus is on human behavior and how machines can imitate intelligent human behavior. AI involves

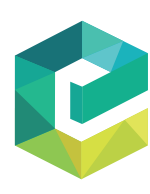

Library Hi Tech Vol. 39 No. 2, 2021 pp. $412-434$ Emerald Publishing Limited $0737-8831$

DOI 10.1108/LHT-02-2020-0038
(C) Asefeh Asemi, Andrea Ko and Mohsen Nowkarizi. Published by Emerald Publishing Limited. This article is published under the Creative Commons Attribution (CC BY 4.0) licence. Anyone may reproduce, distribute, translate and create derivative works of this article (for both commercial \& noncommercial purposes), subject to full attribution to the original publication and authors. The full terms of this licence may be seen at: http://creativecommons.org/licences/by/4.0/legalcode.

This research has been supported by the "Project no. NKFIH-869-4/2019 has been implemented with the support provided from the National Research, Development and Innovation Fund of Hungary, financed under the Tématerületi Kiválósági Program 2019 funding scheme.” 
amongst other expert systems (ESs), fuzzy logic, artificial neural network, evolutionary algorithms, case-based reasoning, image processing, natural language processing, speech recognition and robotics. These areas are not separate, and in many intelligent systems at the same time, two or more AI techniques contribute in problem to solving. AI techniques or tools have utilized in many areas such as business, management, medicine, military etc. Library and information science also have developed in using intelligent systems. "Library management and its activities apply repetitious and time-consuming activities. Hence, in order to increase efficiency and effectiveness, many libraries are moving toward automation of their activities" (Dwivedi et al., 2013). AI techniques give more accuracy to the automation of libraries. The ideas of the utilization of intelligent systems instead of the classic systems in libraries started in 1990. Intelligent systems are used in the library to provide knowledgebased services to users of the library system and end-users. These systems, as a complementary system to the main library system, can make intelligent decisions for the retrieval and use of information resources. The careful decision making of these systems is based on the knowledge created by users in the library system. These systems are an important competitor of human activities in the library. This could have implications for librarians. The presented papers at the 27th Annual Clinic on Library Applications of Data Processing dealt the capabilities relate to the library applications: descriptive cataloging, technical services and collection development, subject indexing, reference services, database searching and document delivery (Lancaster and Smith, 1990). A lot of research has already been made of the various uses of AI technologies in libraries. Even Hsieh and Hall (1989) examined the definition and history of $\mathrm{AI}$ and investigates the body of literature on $\mathrm{AI}$ in "Library Literature" and Lisa. In the same year, O'Neill and Morris (1989) looked at the challenge and implications of ESs technology for LIS. In 1998 under the direction of NCR, Inc. and its Future Mapping ${ }^{\circledR}$ process, experts worked together to map out the best scenario for the libraries of the future (Leslie, 1999). After several years, a fully automated 24/7 online librarian system designed to respond to routine and repeat inquiries from distance learners (Payne and Bradbury, 2002). It seems that AI's applications have been considered in various aspects of library and information science. Based on the review of the major models that exist, the following factors are effective in using human intelligence in information systems:

(1) Understanding the nature of the information needs and defining this need for the system,

(2) Identifying information resources that are relevant to information needs,

(3) Evaluation of existing information resources, evaluation of retrieved information,

(4) Organizing existing information resources, organizing selected information from items retrieved,

(5) Managing existing information resources, managing retrieved information,

(6) Using existing information resources, using retrieved information,

(7) Information and knowledge analysis,

(8) Converting information to knowledge,

(9) Dissemination and transfer of information and knowledge,

(10) Interaction and exchange of information and knowledge.

The above is a very useful list for using AI in scientific databases and library and information affairs. For example, recommender systems are very important in identifying information resources and selecting them. These systems can be very helpful in selecting the right resources

A review: intelligent libraries 
LHT

39,2

414

based on user behavior in using the retrieval system. "However, we probably cannot consider the system to be intelligent by human standards. The fact that we are transient organic beings that possess five senses and feel, as well as think. In short, computers lack: all that man is, all mere complexities, the fury and the mire of human veins." (Bailey, 1991 and Bailey, 1992). Today, many years have passed since research into AI programming techniques and the use of WSs for providing technical services to libraries and information databases and providing public services to end-users. Now the dream of smart libraries has become a reality. Cao et al. (2018) have paid to the conceptualization of the smart library, and scientists and professionals have created systems that can be thought of and decided instead of the librarian. Cox et al. (2018) studied on the intelligent library. They paid to the thought leaders' viewpoints on the impact of AI on the libraries. Even these systems can mimic the librarian's behavior. The purpose of the study is to review the articles on intelligent libraries and the use of Artificial Intelligence (AI), Expert Systems (ESs) and robots in the libraries. The articles retrieved from Web of Science (WoS) as a cumulative database and Emerald Insight as a professional database in library and information science. The research questions are the following:

(1) In WoS, which articles did authors write about ES/AI and robots' application in the library?

(2) In Emerald Insight, which articles did authors write about ES/AI and robots' application in the library?

\section{Artificial intelligence}

$\mathrm{AI}$ applies to different sciences. We can say in the library and information science, it more uses in scientific databases and library systems. Such as behavioral science, social sciences, psychology, management and library science and information science. It is related to some of the systems that apply different forms of intelligence such as learner systems, inferior systems, systems with natural language understanding or natural language interpretation, systems with visual scene perception and systems that perform other types of feat that require human types of intelligence (Bavakutty and Salih, 2006). In this branch of the science that involves machines, solutions are utilized to solve complex problems of human behavior. We can present computer-based algorithms based on human behavior and knowledge in using systems. "It is an interdisciplinary field making use of concepts from various fields like cybernetics, information theory, psychology, linguistics, logic, etc. it can use to simulate human behavior and for computer ailed instruction, ES, robots and for NLP. It can also use for Intelligent Retrieval from databases" (Bavakutty and Salih, 2006). In this way, computer software and the use of various computer-based products help in the operation of various types of libraries and their public services and the generation of output products. Automation implies the degree of mechanization where the routines and receptive jobs or operations are left to be performed by machines with little or no intervention by human beings. Lesser the degree of human intervention, greater the degree of automation; this does not mean that automation does away with human beings. On the contrary, human beings are relieved of routine chores, giving them more time for tasks, which require their intelligence. In view of the various features of a modern computer system, we find that it has been applied in several areas of library work. Book acquisitions, cataloging, serials control, and circulation, information retrieval and dissemination, interlibrary loan, cooperative acquisition and cataloging have been automated in the library (Lakshmikant and Vishnu, 2008).

\section{Intelligent systems}

Intelligent systems (ISs) are defined as any formal or informal system that is able to obtain and process data, to interpret the data by applying technologies of artificial intelligence and 
business intelligence and to provide reasoned judgments based on that to decision makers as a basis for action (Sharda et al., 2017).

ISs are computer-based systems that help in the task of subject indexing can be thought of as an ES (Lancaster, 1997). Lancaster has a clear statement relating to the scope of AI: "Computer programs have been developed, which exhibit human-like reasoning, which may be able to learn from their mistakes and which quickly and cleverly perform tasks normally done by scarce and expensive human experts." AI has a wide application area. Figure 1 gives a good idea of this coverage.

Technologies that are frequently used in intelligent systems: machine learning, case-based reasoning, genetic algorithms, fuzzy logic and natural language processing (NLP).

NLP is another facility of an intelligent system that can use to retrieve information needs from different scientific databases. In the information retrieval process, the user can state his information requirement in natural language, making the searching more easily and fruitful this allows users to state complex retrieval languages (Bavakutty and Salih, 2006).

Business intelligence (BI) as is the set of techniques and tools for the transformation of raw data into meaningful and useful information for business analysis/decision support purposes (Sharda et al, 2017). BI solutions include data access, storage, data analysis and visualization technologies to support better decision making.

\section{Expert systems}

Expert systems (ESs) are computer-based systems that simulate human decision making. They can integrate with information systems to improve their accuracy and performance (Singh et al., 1996). Various librarian ES has been developed. Waters (1986) designed the National Agricultural Library's microcomputer-based ES to help users obtain answers to simple reference questions. In general, they ask questions from the user and take the user's answer as input, then explain the rationale for decision results. In general, these systems consist of two main elements: A knowledge base and inference engine. The knowledge base encompasses all the information needs that human/librarian experts are using to decide. This information is present in the knowledge base as facts and rules. ESs can make much better decisions than librarian decision makers because their knowledge base can involve the experiences of a team of the best experts. The manner of librarian experts to make decisions is emulated for the design rules of the knowledge base. The rules are consisting of two main phases: "if phase" and "then phase." The "if phase" is consisting of conditions, and the "then phase" is consisting of results. ESs are distinguished from other computer systems with the application of reasoning through the inference engine. The inference engine simulates human decision makings based on the knowledge base and a rule base (Figure 2).

The creation of an ES includes the extraction of the relevant knowledge from the expert human, and it is often nature heuristic. ESs use problem-solving in different areas such as

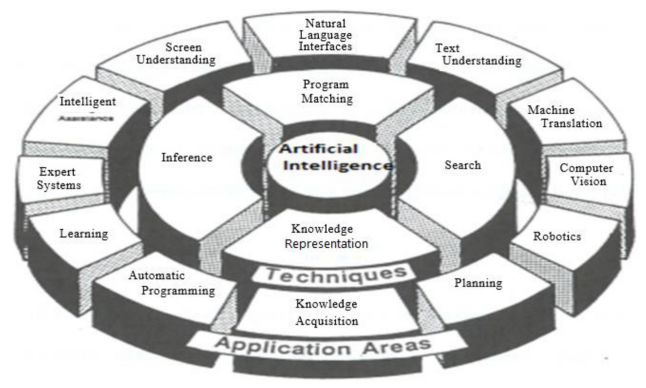

A review: intelligent libraries 
LHT

39,2

416

medicine, business, computer science, law, defense, education, mathematics, engineering, geology, etc. (Bavakutty and Salih, 2006). Many of the library's activities are specialized. For this reason, library software should be used to improve the library's performance. The efforts have been made in this regard. Denning and Smith (1994) had a survey on the "Electronic Library Search Assistant.” Kruk and Krawczyk (2004) studied about intelligent resources search in virtual libraries. Devadason and Vespry (1996) studied about planning for the library staff. It encapsulates the expert knowledge of a library staff planner. They presented the LISPA (Library and Information center Staff Planning Advisor). By reviewing the research and literature, specialized library systems can have the following applications in the area of providing library and information services:

(1) Knowledge-based indexing (Amin and Razmi, 2009);

(2) Natural Language Processing and abstracting (Albayrak and Erensal, 2004);

(3) Reference work (Amin and Razmi, 2009);

(4) Cataloging (Weiss, 1994) and (Amin and Razmi, 2009);

(5) Online information retrieval (Bellman and Zadeh, 1970), (Sacchanand and Jaroenpuntaruk, 2006) and (Bavakutty and Salih, 2006);

(6) Using intelligent interfaces in online information storage and retrieval systems;

(7) Information needs analysis and representation, including different services, such as classification, indexing and abstracting;

(8) Reference services;

(9) Development of collection;

(10) Hypertext and hypermedia (Bavakutty and Salih, 2006).

\section{Methodology}

Descriptive and content review methods are applied to the study. The researchers critically reviewed the articles related to ES/AI and robots in the library. According to this review, the application of ES/AI and robots classified as the following:

Technology: The articles surveyed and evaluated the information management systems in the libraries belongs to this group. These articles relate to usability and implementation. They do not propose or propose an information system or model.

Resource: These articles related to information resources. This category may include the selection, acquisition and use of information resources.

User / End-user: Existing information and knowledge systems/models are usually working based on the opinion of experts/users and end-user behavior. Therefore, applying ES

Figure 2.

ES elements

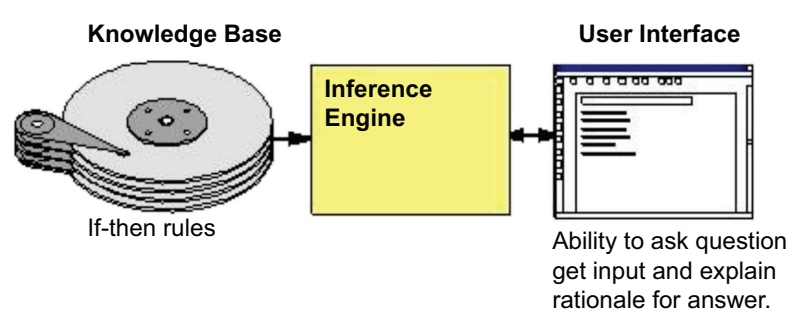


technologies such as inference engine and fact/rule base will improve the performance and accuracy of considered systems.

Service: The articles in this group have proposed an ES or related technology and methods that can be connected and included in ESs to present public or technical services. The public services present to end-users to fulfill their information needs and technical services present to the librarians or any professional user in library activities.

\section{Findings}

The purpose of the study is to review the articles on intelligent libraries and the use of ES/AI and robots in the libraries. Based on the research questions, the findings presented in two sections. The first section is related to the review of the articles in $\mathrm{WoS}$ as a general database in different subjects. The second section is related to the review of the articles in Emerald as a professional database in the Library and Information Science. According to this review, the application of ES/AI and robots classified into four classes such as technology, resource, user/ end-user and service.

\subsection{ES/ AI and robots' application in the library (WoS)}

The topics of "expert system" and "library" were searched in the WoS database on 10th Oct 2017. We found 1,208 documents related to this topic. Then we have refined the topics through "Research Area," "Document Type." In the research area, we selected the area of "Information Science, Library Science." We chose "article" for "document type" and excluded unrelated articles. Finally, found 14 articles as a result, which are shown in Table 1.

The review of papers shows the fading of the ES/AI in recent studies. It is found that the majority ( $46 \%$ ) of the paper worked on the experts'/users' behavior. This is even though no research has been done on the use of intelligent resources using ESs between the years 2007-2017 on the WoS (Figure 3). However, the studies that are related to information systems have a closed relation with the knowledge and opinion of experts. Using ES technologies such as inference engine and fuzzy rule base may increase the accuracy of them. Therefore, the current information systems can be improved by integration with ES technologies. ESs use in intelligent libraries. In general, the information provided to users in a library leads to a change in the behavior of the user's knowledge and creates learning. The intelligent library uses an appropriate protocol for the exchange of information. This protocol is unique, and it is designed to help, confirm or perform the terms of the agreement. The terms of the agreement include a series of guidelines that will be carried out automatically. These guidelines relate to information sources, services, and technology for distributing and exchanging information. For operating a smart library, resources and services must be available under the agreement. All users must use the digital signature and agree to the terms of the agreement. Smart libraries can exchange information based on the internet of Things (IoT).

Recently the researchers tried to increase the ability of librarian robots by applying the new methods. We searched for the topic of "Librarian robot" using WoS on 10th Oct 2017. Then we limited the results to the duration of 2007-2017. We excluded unrelated articles and finally found 15 articles and proceeding papers as a result, which is shown in Table 2 . In this table, we determine the research area related to applied methodologies of papers in the "Research area of publication source." A summary of the applied method is explained in "Method," and the main contribution of papers is mentioned in "contribution."

The most recent papers that are related to librarian robots are in the area of service (Figure 4). Improving the technology of gripping, localizing and human-robot interaction are the most discussed issues in librarian robots. Librarian robots can be used in large libraries. This robot reduces a lot of common and duplicate activities in different places of the library, 


\section{LHT} 39,2

\begin{tabular}{llll}
\hline No. & Author & Contribution & Application based on the reference \\
\hline 1 & $\begin{array}{l}\text { Asemi } \text { et al. } \\
(2012)\end{array}$ & $\begin{array}{l}\text { Management Information } \\
\text { System (MIS) }\end{array}$ & $\begin{array}{l}\text { Supportive tool for library operations and } \\
\text { provides suitably detailed reports in an }\end{array}$ \\
2 & Black (2011) & $\begin{array}{l}\text { Web Content Management consistent and timely manner } \\
\text { System (CMS) }\end{array}$ & $\begin{array}{l}\text { Support a large distributed content model and } \\
\text { shares the CMS trail method used, which } \\
\text { directly included content provider feedback } \\
\text { side-by-side with the technical experts }\end{array}$ \\
& Support context-aware ubiquitous learning
\end{tabular}

\section{8}

(2010)

4 Chu et al.

$$
\text { (2010) }
$$

$5 \quad$ Ding and

Sølvberg

(2007)

6 Golub et al. (2014)

$7 \quad$ Huili and Bo (2017)

8 Hwang et al. (2011)

$9 \quad$ Iglesias (2013)

A grid-based knowledge acquisition approach and a Mind tool is proposed

electronic library with supporting context-aware ubiquitous-learning Rule-based metadata interoperation

Terminology registries (TRs)

Smart library, Library robot

Application Robots in Library

$10 \quad$ Ismail and

Identifying how novice

Kareem (2011)

11 Kao and $\mathrm{Wu}$ (2012)

12 Mehtab Alam Ansari (2008)

13 Mei et al. (2017)

14 Phillips (2017)

AI in Library, Library

Automation and use web resources personalized knowledge integration platform for digital libraries

Online Public Access Catalogue (OPAC)

Intelligent Use of Library
Supporting learning activities conducted in real-world environments

Support querying across distributed digital libraries created in heterogeneous metadata schemas, without requiring the availability of a global schema

Provide the content of knowledge organization systems (KOS) available both for human and machine access

Making the robot more like a librarian, focus on key technologies to take the robot into the real library environment, and cultivate relevant technical talents

Help students organize and share knowledge for differentiating a set of learning targets based on what they have observed in the field Advancements in Library Automation Automating Reference, Storage, Technical Services, Circulation desketc.

Supporting information-seeking behavior of novice researchers by specific research tools

Providers users with personalized information and knowledge services

Allowing a user to search online and retrieve records/catalogue and depending on the underlying library management software/ online reservation, circulation and so on proposes a general framework to establish the dynamic movement primitives library (DMPL) for a mobile robot path planning in an unknown environment

Development in robotics and AI, and the potential implications for library services. It explores the impacts of automation of human work, with a particular focus on recent advances in robotics and $\mathrm{AI}$ and how these may affect library services and library work in future
Class

Technology

User/end-

user

Technology User/end-

user

Technology User/enduser Technology

User/end-

user

Service

User/end-

user

Technology

User/end-

user

Service

User/end-

user

Technology

User/end-

user

Service

User/end-

user

Technology

User/end-

user

Technology

User/end-

user

Technology

User/end-

user

Service

Service

Table 1.

Articles related to ES/

AI and library (WoS) 


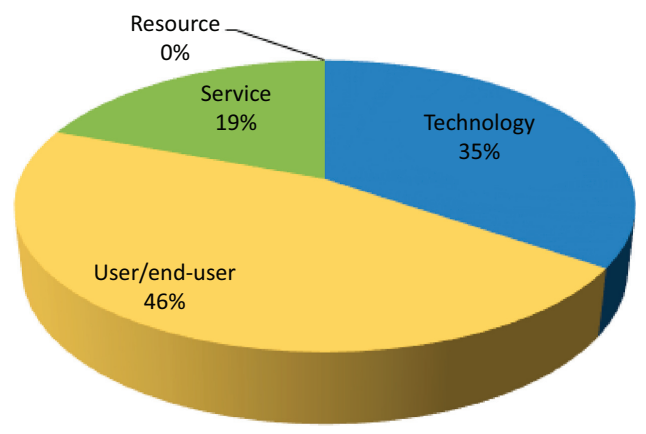

A review: intelligent libraries

Figure 3.

The scope of the articles in the field of

$\mathrm{ES} / \mathrm{AI}$ and library (WoS)

especially at the library's repository. For example, this robot can be helpful in shelf-reading activity. There are some imaginations that the use of librarian robot creates a gap between information and people. Smart libraries and librarian robots are always faced with this challenge. But not a way out of using new technologies, because the development of information does not coincide with the development of expert human resources. In many libraries, librarian robots can be helpful in solving library problems. Only the small number of the studies are related to resources. It is shown that we need to develop our research in this area.

The library should take special care of every aspect related to the man-machine interface: favoring systems standardization, avoiding the accumulation of different equipment, using a clear, brief and direct language, including images and sound, representing reality and reflecting the human mental patterns (De Prado, 2000). AI techniques such as genetic algorithms, artificial neural networks, ESs, and fuzzy logic or hybrid methods can improve librarian robots to reflect human mental patterns.

\subsection{ES and robot's application in the library using Emerald Insight [1]}

Table 3 shows the review of the papers in the field of ES/AI and robots, and library exported from the Emerald Insight as a specific database in the library and information science.

Figure 5 shows the most recent papers exported from Emerald Insight, which are related to ES/AI and robot in the library are in the area of service. The finding is the same as the exported papers from the WoS database.

The following trends show a line graph of the relative frequencies across the main category in the abstracts of the articles (Figure 6). The thematic interaction was observed in the main categories of the articles based on their keywords. Most common categories in the abstracts are digital, information, library, search, and user.

Figure 7 shows a line graph of the relative frequencies across the main category of the keywords of the articles. The thematic interaction was observed in the main categories of the articles based on their keywords. Most common categories in the abstracts are digital, information, Internet, library, and systems.

\section{Discussion}

The ES should be considered only when development is: "possible," "appropriate," and "justified" (Lancaster, 1997). This question must be answered before we initialed an ES project. Waters (1986) gives some good guidelines on when we should consider using ESs. An 


\section{LHT} 39,2

\section{0}

2 Du et al (2011)

3 Grigorescu et al. (2010)

\begin{tabular}{ll}
\hline No & Author \\
\hline 1 & $\begin{array}{l}\text { Comsa et al. } \\
(2014)\end{array}$
\end{tabular}

Presenting some similar state-ofthe-art developments, $\mathrm{CAD}$ models of two book manipulators and also an innovative design approach in designing library book handling gripper mechanisms

Designing an embedded controller for the pneumatic manipulator of library robot

Propose a robust feature extraction for 3D reconstruction of segmented boundary objects

4 Heyer $e t a l$. (2012)

Propose a new approach for detecting and grasping the book reliably

5 Huili and Bo Making the robot more like a (2017) librarian, focus on key technologies to take the robot into the real library environment, and cultivate relevant technical talents

\section{$6 \quad$ Iglesias} (2013)

$7 \quad$ Kim et al. (2009)
Advancements in Library

Automation: Automating Reference, Storage, Technical Services, Circulation Desk, etc.

Propose an information structured environment called $\mathrm{u}-\mathrm{RT}$ to enable a librarian robot to arrange books on bookshelves using ambient intelligence
Table 2.

Articles related to library and robot (WoS)
Application based on the reference Class

Gripper prototype is manufactured using light-weight thermoplastic reinforced material for the mobile finger

Technology Service

Using PC/104 boards system and emphasizing parameter selftuning fuzzy-PID algorithm of the controller

Using means of including

feedback control at image segmentation level for boundary feature extraction. The objective of feedback is to adjust segmentation parameters in order to cope with scene uncertainties, such as variable illumination conditions Robustly extracted 2D object features are provided as input to the 3D object reconstruction module of the FRIEND vision system

Combination of two algorithms for book detection and grasping and users stereo vision together with hand camera to achieve a high rate of success

Based on extensive research literature and best practices of library robots, this paper states robot technology can effectively solve some problems in library management and service, and improve user satisfaction to a certain extent

Different Methods. In this book presented different articles about Automating Reference, Storage, Technical Services, Circulation Desk, etc.

The librarian robot consists of a manipulator to recognize and manipulate books, and a mobile platform to localize itself and navigate using ambient RFID tags embedded in a floor. The proposed u-RT space connects physical and virtual space using physical hyperlinks
Technology Service

Technology Service

Resource

Service

Technology

Service

User/end-

user

Technology

Service

User/enduser

Resource

Service

(continued) 


\begin{tabular}{lll}
\hline No & Author & Contribution \\
\hline 8 & $\begin{array}{l}\text { Kim et al. } \\
(2008)\end{array}$ & $\begin{array}{l}\text { Realize ambient intelligence in } \\
\text { the ubiquitous robot technology } \\
\text { space }\end{array}$
\end{tabular}

9 Kim et al. (2013)

10 Lin et al. (2013)

11 Mei et al. (2017)

12 Mikawa (2010)

13 Modler et al. (2014)

14 Modler et al. (2012)
Application based on the reference

Class

The ubiquitous space for the robotic library is introduced and an RFID technology-based approach for the librarian robot proposed

College students interacted with a social robot in a between-subjects experiment with two manipulated conditions: one where the robot played the role of an ophthalmologist and one where participants played the role of the ophthalmologist

Describe the process of developing an assistant robot with locating resources in libraries. Consulting the stakeholders, including child patrons and librarians. Analyzing the needs and incorporating into the design of library robot Mathematical model: before the library is building, the workspace of the mobile robot is divided into multiple sectors through a unique sampling technique. Then, using a joystick, a user operates the mobile robot moving from start to any sample point, simultaneously recording the states such as position, velocity and acceleration. The primitives will be extracted from the recorded state sequence, and the learned weights will be stored in the DMPL. In the second phase, the DMPL is used online to supply the path planning decision Providing a training ground for creating new types of contents for the Internet age, where students of several specialized fields come together

The gripper CAD model and the experimental gripper prototype, developed using light-weight thermoplastic reinforced material for the mobile finger

The parallel gripper prototype is still in the manufacturing process using light-weight glass-fiber reinforced material user

user

user
Technology

A review: intelligent libraries

User/endService

User/end-

Service

Service

User/end-

Service

Resource

Service

Resource

Service The CAD model for the gripper and FEM simulation is presented 


\section{LHT}

39,2

\begin{tabular}{|c|c|c|c|c|}
\hline No & Author & Contribution & Application based on the reference & Class \\
\hline 15 & $\begin{array}{l}\text { Phillips } \\
\text { (2017) }\end{array}$ & $\begin{array}{l}\text { Developments in robotics and AI, } \\
\text { and the potential implications for } \\
\text { library services. It explores the } \\
\text { impacts of automation of human } \\
\text { work, with a particular focus on } \\
\text { recent advances in robotics and } \\
\text { AI and how these may affect } \\
\text { library services and library work } \\
\text { in future }\end{array}$ & $\begin{array}{l}\text { An in-depth literature review, and } \\
\text { the results of original research. } \\
\text { The research consisted of a survey } \\
\text { of the general population, } \\
\text { including library users and } \\
\text { workers, and a focus group with } \\
\text { library workers only. Key themes } \\
\text { explored include: general } \\
\text { perceptions and experience of } \\
\text { automation in libraries, potential } \\
\text { acceptance levels of robots being } \\
\text { used in libraries, and the predicted } \\
\text { positive and negative outcomes }\end{array}$ & Service \\
\hline
\end{tabular}

Table 2.

Figure 4 .

The scope of the articles in the field of library and robot $(\mathrm{WoS})$

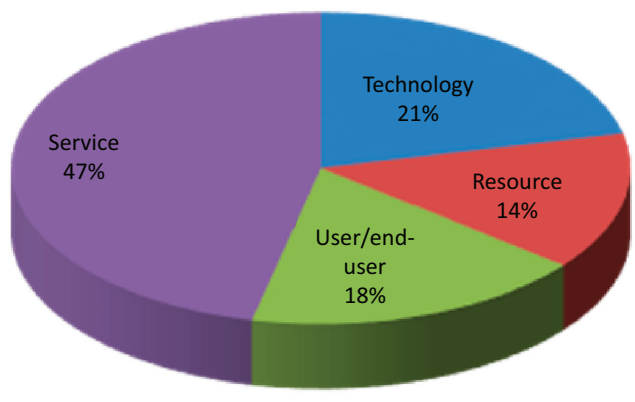

ES has received a lot of attention from the research community in the 1980s. Unfortunately, much of the writing sensationalized the field expectations dramatically (Lakshmikant and Vishnu, 2008) fueled by public expectations began to over-promise misconceptions about what AI can and cannot do arise and they persist today. Many rushed into the field in search of quick answers and quick profits. Several Al researchers saw what was happing and feared a backlash. Once all the excitement wore off during 1988-90, things did begin to change some of the realities and limitations of the AI techniques became evident. An AI backlash has resulted in ascertaining to an extent, but fortunately, it has not been wide-scaled instead. The optimism remains with a better sense of realism than before, and both the benefits and limitations are better appreciated.

In general, in the protocol of an intelligent library, clear the subject of the agreement, the digital signature, and the divisional platform must be clear. Smart library agreements can be applied in various fields, including the acquisition of information resources, presenting public services to the end-user, technical services, management, and many other library activities in many library activities. Advantages of intelligent libraries are the security of information, the cost of services, the speed of service to the user community, the pursuit of activities within the framework of the standard. Problems that may be encountered in intelligent libraries are human factor problems, the cost of implementing intelligent library agreements, and copyright issues. One of the key elements in the smart library is digital identity. Based on the intelligent library protocol, users can create or control their digital identities. This digital identity includes information, reputation and information resources used or required by the users. Smart library users in the context of the IoT can decide which information to be 


\begin{tabular}{|c|c|c|c|c|c|}
\hline No & Author/s & Keywords & $\begin{array}{l}\text { Application based on the } \\
\text { reference }\end{array}$ & Class & $\begin{array}{l}\text { A review: } \\
\text { intelligent }\end{array}$ \\
\hline 1 & $\begin{array}{l}\text { Ataman Kemal } \\
(2009)\end{array}$ & $\begin{array}{l}\text { Archives management, library } \\
\text { Information science, Records } \\
\text { management, Information } \\
\text { profession }\end{array}$ & $\begin{array}{l}\text { Library services present by } \\
\text { the smart talking robot Xiaotu } \\
\text { based on artificial intelligence }\end{array}$ & Service & \\
\hline 2 & Bi et al. (2017) & $\begin{array}{l}\text { Internet of things, Planning and } \\
\text { control, Robot, System interaction, } \\
\text { Wireless sensors network (WSN) }\end{array}$ & $\begin{array}{l}\text { The application of intelligent } \\
\text { agents in library services }\end{array}$ & Service & 423 \\
\hline 3 & $\begin{array}{l}\text { Bilandzic and } \\
\text { Foth (2013) }\end{array}$ & $\begin{array}{l}\text { Library as a place, Technology- } \\
\text { enhanced learning, Library 2.0, } \\
\text { Commons 2.0, Coworking, Urban } \\
\text { informatics, library, User studies, } \\
\text { Australia Learning }\end{array}$ & $\begin{array}{l}\text { Using library } 2.0 \text { tools in the } \\
\text { library services and user } \\
\text { learning }\end{array}$ & $\begin{array}{l}\text { User/End- } \\
\text { user } \\
\text { Service }\end{array}$ & \\
\hline 4 & $\begin{array}{l}\text { Borgman } \\
(2000)\end{array}$ & $\begin{array}{l}\text { Electronic publishing, library, } \\
\text { Computer networks }\end{array}$ & $\begin{array}{l}\text { The application Web } 2.0 \text { tools } \\
\text { for the electronic publishing }\end{array}$ & Resource & \\
\hline 6 & $\begin{array}{l}\text { Chen and } \\
\text { Hsiang (2009) }\end{array}$ & $\begin{array}{l}\text { Generation and dissemination of } \\
\text { Information, Digital storage, } \\
\text { Academic Library, Open systems }\end{array}$ & $\begin{array}{l}\text { Web information seeking and } \\
\text { retrieval in digital library } \\
\text { contexts based on the } \\
\text { artificially intelligent }\end{array}$ & $\begin{array}{l}\text { Resource } \\
\text { Service }\end{array}$ & \\
\hline 7 & $\begin{array}{l}\text { Chowdhury } \\
\text { (1999) }\end{array}$ & $\begin{array}{l}\text { Internet, Information services, } \\
\text { Information retrieval }\end{array}$ & $\begin{array}{l}\text { Digital library using context- } \\
\text { awareness technology }\end{array}$ & $\begin{array}{l}\text { Resource } \\
\text { Service }\end{array}$ & \\
\hline 8 & $\begin{array}{l}\text { Connolly } \\
(2008)\end{array}$ & $\begin{array}{l}\text { Artificial intelligence, Robotics, } \\
\text { Pattern recognition }\end{array}$ & $\begin{array}{l}\text { The application mobile for } \\
\text { library services }\end{array}$ & $\begin{array}{l}\text { Resource } \\
\text { Service }\end{array}$ & \\
\hline 9 & $\begin{array}{l}\text { Dimić et al. } \\
(2010)\end{array}$ & $\begin{array}{l}\text { Cataloging Bibliographic standards } \\
\text { Extensible Markup Language } \\
\text { Information systems }\end{array}$ & $\begin{array}{l}\text { RFID integrated systems and } \\
\text { libraries }\end{array}$ & Technology & \\
\hline 10 & Dutton (2014) & $\begin{array}{l}\text { Open systems, Communication } \\
\text { technologies, Surveillance, Internet } \\
\text { of Things, Consumers, Social } \\
\text { behavior }\end{array}$ & Users and electronic libraries & End-user & \\
\hline 11 & $\begin{array}{l}\text { Frederick } \\
(2016)\end{array}$ & $\begin{array}{l}\text { Data, library, Fourth Industrial } \\
\text { Revolution }\end{array}$ & $\begin{array}{l}\text { Enterprise knowledge portals } \\
\text { based on the industry } 4.0\end{array}$ & User & \\
\hline 12 & Gelfand (1998) & $\begin{array}{l}\text { Grey literature, Internet, Publishing } \\
\text { Science }\end{array}$ & $\begin{array}{l}\text { :The application a roboti } \\
\text { digital content: Breedbot }\end{array}$ & Resource & \\
\hline 13 & Hahn (2012) & $\begin{array}{l}\text { Mobile computing, Library } \\
\text { software, Augmented reality, } \\
\text { Computer vision, Smartphones, } \\
\text { Mobile applications, Library } \\
\text { systems, Mobile communication } \\
\text { systems, } \\
\text { Citation }\end{array}$ & Networked library services & Service & \\
\hline 14 & $\begin{array}{l}\text { Islam and } \\
\text { Ikeda (2014) }\end{array}$ & $\begin{array}{l}\text { Knowledge management, Library } \\
\text { services, Digital library, Online } \\
\text { services, WWW }\end{array}$ & Online digital reference & $\begin{array}{l}\text { Resource } \\
\text { Service }\end{array}$ & \\
\hline 15 & Joint (2009) & $\begin{array}{l}\text { Communication technologies, } \\
\text { University library, Worldwide web }\end{array}$ & $\begin{array}{l}\text { Sharing technology of the } \\
\text { experiences in the library }\end{array}$ & Technology & \\
\hline 16 & $\begin{array}{l}\text { Kapoor et al. } \\
(2014)\end{array}$ & Adoption, TAM, RFID, Use & Library Web site management & Technology & \\
\hline 17 & $\begin{array}{l}\text { Kesselman } \\
(2017)\end{array}$ & $\begin{array}{l}\text { Library Education Technology } \\
\text { Conferences Emerging } \\
\text { Technologies Consumer electronics }\end{array}$ & $\begin{array}{l}\text { Virtual reference librarians } \\
\text { (Chatbots) }\end{array}$ & Service & \\
\hline 18 & $\begin{array}{l}\text { Lam and Chan } \\
(2007)\end{array}$ & Archiving, Digital library & $\begin{array}{l}\text { Libraries, data and the fourth } \\
\text { industrial revolution }\end{array}$ & Recourse & $\begin{array}{r}\text { Articles related to ES/ } \\
\text { AI and Robot in the } \\
\text { library (Emerald }\end{array}$ \\
\hline & & & & (continued) & \\
\hline
\end{tabular}




\begin{tabular}{|c|c|c|c|c|}
\hline No & Author/s & Keywords & $\begin{array}{l}\text { Application based on the } \\
\text { reference }\end{array}$ & Class \\
\hline 19 & Liu (2011) & $\begin{array}{l}\text { Intelligent agents, Artificial } \\
\text { intelligence, library, Information } \\
\text { services, Digital library, Library } \\
\text { systems }\end{array}$ & $\begin{array}{l}\text { Metadata and cataloging } \\
\text { practices }\end{array}$ & Service \\
\hline 20 & $\begin{array}{l}\text { McDonnell and } \\
\text { Shiri (2011) }\end{array}$ & $\begin{array}{l}\text { Information retrieval, Search } \\
\text { engines, Design, User interfaces, } \\
\text { Worldwide web, Consumer } \\
\text { behavior }\end{array}$ & $\begin{array}{l}\text { Information retrieval and user } \\
\text { interface }\end{array}$ & $\begin{array}{l}\text { User/ End- } \\
\text { user }\end{array}$ \\
\hline 21 & $\begin{array}{l}\text { Miglino et al. } \\
\text { (2008) }\end{array}$ & $\begin{array}{l}\text { Robotics, Evolution, Education, } \\
\text { Entertainment }\end{array}$ & $\begin{array}{l}\text { XML schema for UNIMARC } \\
\text { and MARC } 21\end{array}$ & Service \\
\hline 22 & $\begin{array}{l}\text { Milella et al. } \\
(2008)\end{array}$ & $\begin{array}{l}\text { Surveillance, Radio waves, } \\
\text { Robotics, Environmental } \\
\text { management, Workplace security }\end{array}$ & $\begin{array}{l}\text { Collaborative digital } \\
\text { reference: An Ask a Librarian } \\
\text { (UK) overview }\end{array}$ & Service \\
\hline 23 & Noh (2013) & $\begin{array}{l}\text { Context-aware computing, } \\
\text { Next-generation digital library, } \\
\text { Ubiquitous library, } \\
\text { Context-awareness technology, } \\
\text { Intelligent space, Sensor, library, } \\
\text { Information systems }\end{array}$ & $\begin{array}{l}\text { What is trending in libraries } \\
\text { from the Internet } \\
\text { cybersphere-AI and other } \\
\text { emerging technologies }\end{array}$ & $\begin{array}{l}\text { Resource } \\
\text { Technology }\end{array}$ \\
\hline 24 & Oyelude (2017) & AI Emerging technologies & $\begin{array}{l}\text { The intelligent library: } \\
\text { Thought leaders' views on the } \\
\text { likely impact of AI on } \\
\text { academic libraries }\end{array}$ & Technology \\
\hline 25 & $\begin{array}{l}\text { Park and Kim } \\
\text { (2013) }\end{array}$ & $\begin{array}{l}\text { Long-term evolution, Technology } \\
\text { acceptance, Perceived mobility, } \\
\text { Perceived adaptively, System and } \\
\text { service quality, Satisfaction Mobile } \\
\text { communication systems, User } \\
\text { satisfaction }\end{array}$ & $\begin{array}{l}\text { Libraries as coworking } \\
\text { spaces: user motivations and } \\
\text { social learning }\end{array}$ & $\begin{array}{l}\text { User/ End- } \\
\text { user } \\
\text { Service }\end{array}$ \\
\hline 26 & $\begin{array}{l}\text { Park et al. } \\
\text { (2015) }\end{array}$ & $\begin{array}{l}\text { User studies, User satisfaction, } \\
\text { Books }\end{array}$ & Reading e-book devices & $\begin{array}{l}\text { Resource } \\
\text { User/ End- } \\
\text { user }\end{array}$ \\
\hline 27 & Rudall (2006) & $\begin{array}{l}\text { Automation, Computers, } \\
\text { Cybernetics }\end{array}$ & Library automation & Technology \\
\hline 28 & Taha (2012) & $\begin{array}{l}\text { Networked library, Research } \\
\text { information, Digital contents, Query } \\
\text { processing, Academic library, } \\
\text { Library networks }\end{array}$ & $\begin{array}{l}\text { AI and robotic hand-eye } \\
\text { coordination in the library }\end{array}$ & Resource \\
\hline 29 & Vincze (2017) & Chatbots & $\begin{array}{l}\text { Knowledge management in } \\
\text { digital libraries }\end{array}$ & Service \\
\hline 30 & Wu et al. (2010) & $\begin{array}{l}\text { Digital library, Resources, } \\
\text { Copyright law, Colleges, Students }\end{array}$ & Digital libraries and resources & Resource \\
\hline 31 & $\begin{array}{l}\text { Xiaobin and } \\
\text { Jing (2009) }\end{array}$ & $\begin{array}{l}\text { Computer applications, Innovation, } \\
\text { User interfaces, Communication, } \\
\text { Digital library }\end{array}$ & $\begin{array}{l}\text { Teaching and exposing grey } \\
\text { literature in the library }\end{array}$ & $\begin{array}{l}\text { User/ End- } \\
\text { user }\end{array}$ \\
\hline 32 & Yaoet al. (2015) & $\begin{array}{l}\text { Artificial intelligence, Promotion, } \\
\text { Participatory library service, Social } \\
\text { networking, Talking robot, Virtual } \\
\text { reference service }\end{array}$ & $\begin{array}{l}\text { Intelligent search agent in the } \\
\text { library }\end{array}$ & Service \\
\hline 33 & $\begin{array}{l}\text { Zimerman } \\
(2012)\end{array}$ & $\begin{array}{l}\text { Digital natives, Search behaviour, } \\
\text { Academic library, Millennials } \\
\text { Information searches, Search } \\
\text { engines, Searchers }\end{array}$ & $\begin{array}{l}\text { Requirements for information } \\
\text { professionals in a digital } \\
\text { environment }\end{array}$ & $\begin{array}{l}\text { User/ End- } \\
\text { user } \\
\text { Service }\end{array}$ \\
\hline
\end{tabular}

Table 3. 
transmitted to them, and this opportunity provides an understanding of the user's information behavior. Smart library agreements can facilitate the post-exchange process of information so that the librarian and user will no longer need to be involved. The exchange of information in intelligent libraries will help smart city innovation. In the following is stated the requirements for the development of an ES:

(1) An expert of the problem available;

(2) Experts have the time for the ES development project;

(3) Experts can articulate their knowledge and methods;

(4) The problem is not too complex, but knowledge intensive;

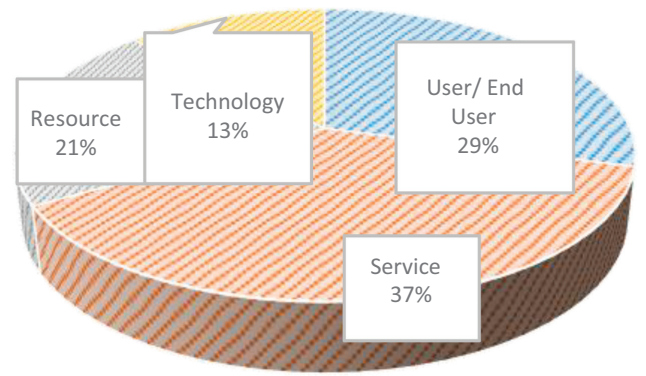

(5) The problem is not poorly understood;

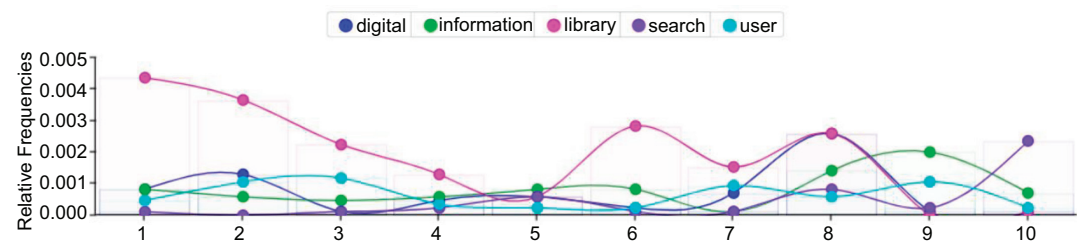

Figure 6.

Relative frequencies across the main categories in the abstracts of the articles and thematic interaction between them in the field of ES/ $\mathrm{AI}$ and robot and library (Emerald Insight)

(6) The problem requires cognitive skills only.

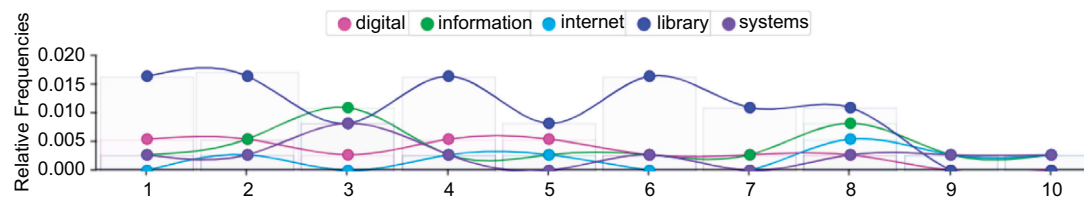

Figure 7.

Relative frequencies across the main categories in the keywords of the articles and thematic interaction between them in the field of ES/ $\mathrm{AI}$ and robot and library (Emerald Insight) 
LHT

39,2

Results are measurable and can be agreed upon by the experts (Lancaster, 1997). An obvious potential application of ES within libraries is for the selection of booksellers or other vendors of library materials carried to its logical conclusion. A system might be developed to select a vendor to automate ethical based on past performance in the supply of publications of a particular type such a capability would be especially valuable in the acquisition of material that is less routine-conference proceeding. A similar system, known as the Monographic Acquisitions consultant, was developed at Lowa State University in 1944. The system was designed to optimize the decision on which vendors are preferred. Types of monographs in the knowledge base of the system includes both descriptive and evaluative data on each supplier. Descriptive data deal with the type of publisher (foreign, university press, the publication of science materials) and relationship with the library (blanket order, approval plan, standing orders on the exchange list (Lakshmikant and Vishnu, 2008). Edelman (2006) studied about an intelligent design in the American Research Library Collections. Fourie (2003) investigated Current Awareness Services (CAS) in library acquisitions. Carneiro (2001) explained the role of intelligent resources in knowledge management. Switching Brains is a cloud-based Intelligent Resources Management (IRM) for the internet of Cognitive Things (IoCT) (Francisco and Arsenio, 2015). Other ESs, designed to help library users satisfy their own needs, have also included document- orders aid (Lakshmikant and Vishnu, 2008). Systems have also been designed within the library community to aid in the selection process, systems of this type have been discussed by Sowell (1989) and Meador and Cline (1992) (Lakshmikant and Vishnu, 2008). The term "referral system," as used here, relates to systems that and are designed to refer library users to information sources likely to provide the answer to a particular question of the factuality of "information" type within the library community more work has been done on a system of this kind than on any other ES. Bailey (1992) studied about reference information system. He tries to help the user to select the appropriate printed and electronic references by ES. Other research has studied about the remote reference service. This study explores the possibilities afforded for collaborative reference work (Davenport et al., 1997). The application mostly such systems refer to users' printed sources like Conventional reference books; but other types of sources, such as those in CD-ROM form, can also be included in the knowledge base. The objective of such systems is obvious: to guide library users with a reference suitable source when a librarian is not available to help them form reference, referral system cover knowledge as a whole in the coverage of a general reference library while others are restricted to the highly specialized domain (Mishra and Srivastava, 2008). One of the most important application of artificial intelligence in libraries is the use of recommender systems. Investigating user behavior in information retrieval and privatizing user services can effectively address his/her information needs in the least amount of time. The different techniques of recommender systems, the properties of these systems, and the evaluation's methods of these systems, provide the best services and resources available to the user. Today, library systems include the hardware and software systems that are applied to different library process activities. As libraries present a huge content of printed materials, the automation of books handling becomes necessary (Comsa et al., 2014). The librarian robot contains manipulation that can identify books. It moves using RFID tags installed on the library shelves. "Jaume" is a librarian robot, which was developed in the Robotic Intelligence Lab of Universitat Jaume I. The new Bordeaux Public Library (June 1991). It offers a special video collection of more than 600 of the information resources. It uses a robot to give the users' consultant service or reference service (Giannattasio and Bruckmann, 1992). UJI librarian robot searches and retrieves the requested books by users. The process starts when the user requests a book by its title or code, either through the Internet or by voice. The robot locates the book and gives it to the user. The book's initial information is read by the robot's vision system. This general application integrates several inter-disciplinary skills like path planning, visual perception or 
multisensory-based grasping, all linked together by reasoning capabilities (Prats et al., 2008; Prats et al., 2007; Ramos-Garijo et al., 2003). A librarian robot evaluates with the following criteria:

(1) Reliable visual localization;

(2) Robust and fault-tolerant force-guided extraction;

(3) Performance adequate for books of different sizes and thicknesses;

(4) Active book searching;

(5) Combine navigation and active vision;

(6) Fault-tolerant probabilistic strategy.

In the context of robot librarians and AI has been investigated by limited number of studies. In the database of Emerald, only one article was found (Yao et al., 2015). They introduced a collaborative library service based on artificial intelligence. They developed an intelligent robot called Xiaotu (female). The task of this robot is to provide online reference services. Four factors are important in the success of this robot: artificial intelligence, self-learning, vivid logo and language, and modular architecture (Yao et al., 2011). Yuehu and Yanqing (2012) studied using the internet technology of objects. They have tried to look at smart sets along with the robot librarian. Then compare the smart library with other libraries. Kyrarini et al. (2017) presented a framework called "Skill Robot Library" (SRL). This framework has the authority to store key points of the route. In fact, this robot can store user's behavior in information retrieval, and it will work based on this stored behavior. Behan and O'Keeffe (2009) designed as a mobile robotic assistant, called "LUCAS" for the University of Limerick. This assistant is a help system that supports users intellectually. Kim and Kohtaro (2009) tried to provide robots based on the structured data. This study introduces a conventional and intelligent environment for a librarian robot. This environment is based on RFID technology for these systems. In another study, reference services were investigated using the instant messaging (IM) smart robot. The Shanghai Jiaotong University Library is presented for example. This library provides the IM robot's intelligent library service using BotPlatform (Yi et al., 2011).

\section{Conclusion}

A review of the articles shows that we can use expert and intelligence systems in different library activities and information services. The main goal is to provide specialized services with the help of librarians and information resources specialists. Library services include technical and public services. Both categories use intelligent systems and ESs. These activities include the provision of information resources, the organization of information resources such as classification, indexing, and abstracting, the storage and retrieval of information from library systems, reference services, and circulation desk. We classified the scopes of the researches into four classes "technology," "user," "service," and "resource." A review of the articles shows that users' information behavior is a very good way to design intelligent systems. The storing information in cloud and non-cloud spaces allow for the development of these systems. In big data and social networks where scientific information resources are exchanged, intelligent agents can play an important role. User profiles can be a good source for designing ES algorithms based on user knowledge. ESs are the most useable intelligent system in library and information science, which mimic librarian expert's behaviors to support decision and management. However, individually using this technology is reduced in recent studies. Most information systems have a closed relation with the knowledge and opinion of experts. Using ES technologies such as inference engine and fuzzy 
LHT

39,2

rule base may increase the accuracy of them. Therefore, the current information systems can be improved by integration with ES technologies. The librarian robot can reduce the usual and repetitive activities on library shelves. Almost the third of the articles in Emerald Insight in ES have related to the "user" scope, and in librarian robot (18\% in WoS), most of the articles have related to the "service" in Emerald Insight and in WoS as well. One of our conclusion is that we need to further research in the area of smart resources.

\section{Note}

1. https:/www.emerald.com/insight

\section{References}

Albayrak, E. and Erensal, Y.C. (2004), "Using analytic hierarchy process (AHP) to improve human performance: an application of multiple criteria decision making problem", Journal of Intelligent Manufacturing, Vol. 15 No. 4, pp. 491-503, doi: 10.1023/B:JIMS.0000034112.00652.4c.

Amin, S.H. and Razmi, J. (2009), "An integrated fuzzy model for supplier management: a case study of ISP selection and evaluation”, Expert Systems with Applications, Vol. 36 No. 4, pp. 8639-8648, available at: http://isiarticles.com/bundles/Article/pre/pdf/19174.pdf.

Asemi, A., Akbari, A., Kheradmandnia, M. and Farazi, A. (2012), "Investigating the level of desirability of information in management information systems in libraries in Iran", The Electronic Library, Vol. 30 No. 6, pp. 833-843, doi: 10.1108/02640471211282136.

Ataman, B.K. (2009), "Requirements for information professionals in a digital environment: some thoughts", Program Electronic Library and Information Systems, Vol. 43 No. 2, pp. 215-228, doi: 10.1108/00330330910954415.

Bailey, C.W. Jr. (1991), "Intelligent library systems: artificial intelligence technology and library automation systems", in Hewitt, J.A. (Ed.) Advances in Library Automation and Networking, Vol. 4, JAI Press, Greenwich, CT, available at: http://www.digital-scholarship.org/cwb/intlibs. pdf (accessed 20 June 2018).

Bailey, C.W. (1992), "The intelligent reference information system project. A merger of CD-ROM LAN and expert system technologies", Information Technology and Libraries, Vol. 11 No. 3, p. 237, available at: https://www.learntechlib.org/p/146739/ (accessed 21 April 2019).

Bavakutty, M. and Salih, M. (2006), Research on Library Computerisation, 1st ed., Ess Ess Publications.

Behan, J. and O'Keeffe, D.T. (2009), "The development of an intelligent library assistant robot (Ireland)", Journal of Korea Robotics Society, Vol. 4 No. 2, pp. 147-154.

Bellman, R.E. and Zadeh, L.A. (1970), "Decision-making in a fuzzy environment", Management Science, Vol. 17 No. 4, pp. B141-B164, doi: 10.1287/mnsc.17.4.B141.

Bi, Z., Wang, G., Xu, L.D., Thompson, M., Mir, R., Nyikos, J., Mane, A., Witte, C. and Sidwell, C. (2017), "IoT-based system for communication and coordination of football robot team", Internet Research, Vol. 27 No. 2, pp. 162-181, doi: 10.1108/IntR-02-2016-0056.

Bilandzic, M. and Foth, M. (2013), "Libraries as coworking spaces: understanding user motivations and perceived barriers to social learning", Library Hi Tech, Vol. 31 No. 2, pp. 254-273, doi: 10.1108/07378831311329040.

Black, E.L. (2011), "Selecting a web content management system for an academic library website", Information Technology and Libraries, Vol. 30 No. 4, pp. 185-189, doi: 10.6017/ital.v30i4.1869.

Borgman, C.L. (2000), "Digital libraries and the continuum of scholarly communication", Journal of Documentation, Vol. 56 No. 4, pp. 412-430, doi: 10.1108/EUM0000000007121.

Cao, G., Liang, M. and Li, X. (2018), "How to make the library smart? The conceptualization of the smart library", The Electronic Library, Vol. 36 No. 5, pp. 811-825, doi: 10.1108/EL-112017-0248. 
Carneiro, A. (2001), "The role of intelligent resources in knowledge management", Journal of Knowledge Management, Vol. 5 No. 4, pp. 358-367, doi: 10.1108/eum0000000006533.

Chen, K. and Hsiang, J. (2009), "The unique approach to institutional repository, practice of National University", The Electronic Library, Vol. 27 No. 2, pp. 204-221, doi: 10.1108/ 02640470910947566.

Chowdhury, G.G. (1999), "The Internet and information retrieval research: a brief review”, Journal of Documentation, Vol. 55 No. 2, pp. 209-225, doi: 10.1108/EUM0000000007144.

Chu, H.C., Hwang, G.J. and Tseng, J.C.R. (2010), "An innovative approach for developing and employing electronic libraries to support context-aware ubiquitous learning", The Electronic Library, Vol. 28 No. 6, pp. 873-890, doi: 10.1108/02640471011093552.

Comsa, A., Maniu, I., Modler, N., Lovasz, E.C. and Ciupe, V. (2014), "Automated book manipulator in libraries", in Pisla, D., Bleuler, H., Rodic, A., Vaida, C. and Pisla, A. (Eds), New Trends in Medical and Service Robots. Mechanisms and Machine Science, Vol. 16, Springer, Cham, doi: 10.1007/9783-319-01592-7_6.

Connolly, C. (2008), "Artificial intelligence and robotic hand-eye coordination", Industrial Robot: International Journal, Vol. 35 No. 6, pp. 496-503, doi: 10.1108/01439910810909484.

Cox, A.M., Pinfield, S. and Rutter, S. (2018), "The intelligent library: thought leaders' views on the likely impact of artificial intelligence on academic libraries", Library Hi Tech, Vol. 37 No. 3, pp. 418-435, doi: 10.1108/LHT-08-2018-0105.

Davenport, E., Procter, R. and Goldenberg, A. (1997), "Distributed expertise: remote reference service on a metropolitan area network", The Electronic Library, Vol. 15 No. 4, pp. 271-278, doi: 10.1108/ eb045567de.

De Prado, R.L. (2000), "Do users dream of electronic libraries?”, The Electronic Library, Vol. 18 No. 3 , pp. 202-209, doi: 10.1108/02640470010337508.

Denning, R. and Smith, P.J. (1994), "Interface design concepts in the development of Elsa, an intelligent electronic library search assistant", Information Technology and Libraries, Vol. 13 No. 2, pp. 133-147.

Devadason, F.J. and Vespry, H.A. (1996), "LISPA (library and information center staff planning advisor): a microcomputer-based system”, Information Technology and Libraries, Vol. 15 No. 2, pp. 105-112.

Dimić, B., Milosavljević, B. and Surla, D. (2010), "XML Schema for UNIMARC and MARC 21", The Electronic Library, Vol. 37 No. 3, pp. 418-435, doi: 10.1108/02640471011033611.

Ding, H. and Sølvberg, I. (2007), "Rule-based metadata interoperation in heterogeneous digital libraries”, The Electronic Library, Vol. 25 No. 2, pp. 193-206, doi: 10.1108/02640470710741322.

Du, M., Fang, J. and Wang, L. (2011), “A parameter self-tuning fuzzy-PID control system for pneumatic manipulator of library robot", Paper presented at the International Conference on Electronics, Communications and Control (ICECC), 9-11 Sep, Ningbo, China, doi: 10.1109/ICECC.2011. 6067700 .

Dutton, W.H. (2014), "Putting things to work: social and policy challenges for the internet of things", Info, Vol. 16 No. 3, pp. 1-21, doi: 10.1108/info-09-2013-0047.

Dwivedi, Y.K., Kapoor, K.K., Williams, M.D. and Williams, J. (2013), "RFID systems in libraries: an empirical examination of factors affecting system use and user satisfaction", International Journal of Information Management, Vol. 33 No. 2, pp. 367-377, doi: 10.1016/j.ijinfomgt.2012. 10.008 .

Edelman, H. (2006), "Intelligent design and the evolution of American research library collections", Library Resources and Technical Services, Vol. 50 No. 4, pp. 234-238, doi: 10.5860/1rts.50n4.234.

Fourie, I. (2003), "How can current awareness services (CAS) be used in the world of library acquisitions?", Online Information Review, Vol. 27 No. 3, pp. 183-195, doi: 10.1108/ 14684520310481409 .

A review: intelligent libraries 
LHT

39,2

Francisco, R. and Arsenio, A.M. (2015), "Switching brains: cloud-based intelligent resources management for the internet of cognitive things", EAI Endorsed Transactions on Cognitive Communications, Vol. 1 No. 2, pp. 1-13, doi: 10.4108/cogcom.1.2.e4.

Frederick, D. E. (2016), "Libraries, data and the fourth industrial revolution (Data Deluge Column)", Library Hi Tech News, Vol. 33 No. 5, pp. 9-12, doi: 10.1108/LHTN-05-2016-0025.

Gelfand, J. (1998), "Teaching and exposing grey literature: what the information profession needs to know-examples from the sciences”, Collection Building, Vol. 17 No. 4, pp. 159-166, doi: 10.1108/ 01604959810238301.

Giannattasio, I. and Bruckmann, D. (1992), "An update of audiovisual and new technology in French libraries", IFLA Journal-International Federation of Library Associations, Vol. 18 No. 3, pp. 252-257, doi: 10.1177/034003529201800313.

Golub, K., Tudhope, D., Zeng, M.L. and Zumer, M. (2014), "Terminology registries for knowledge organization systems: functionality, use, and attributes", Journal of the Association for Information Science and Technology, Vol. 65 No. 9, pp. 1901-1916, doi: 10. 1002/asi.23090.

Grigorescu, S.M., Natarajan, S.K., Mronga, D. and Graser, A. (2010), "Robust feature extraction for 3D reconstruction of boundary segmented objects in a robotic library scenario", Paper presented at the International Conference on Intelligent Robots and Systems (IROS), IEEE/RSJ, 18-22 Oct. Taipei, Taiwan.

Hahn, J. (2012), "Mobile augmented reality applications for library services", New Library World, Vol. 113 Nos 9/10, pp. 429-438, doi: 10.1108/03074801211273902.

Heyer, S., Enjarini, B., Fragkopoulos, C. and Graeser, A. (2012), "Book detection and grasping in library scenario", Paper presented at the ROBOTIK 2012; 7th German Conference on Robotics, 21-22 May, Munich, Germany.

Hsieh, C.C. and Hall, W. (1989), "Survey of artificial-intelligence and expert systems in library and information-science literature", Information Technology and Libraries, Vol. 8 No. 2, pp. 209-214, available at: https://www.learntechlib.org/p/170528/ (accessed 21 April 2019).

Huili, F. and Bo, Sh. (2017), "A review on researches and practices of library robots at home and abroad”, Library Journal, Vol. 36 No. 6, pp. 88-94, available at: http://www.libraryjournal.com. cn/EN/Y2017/V36/I6/88 (accessed 21 April 2019).

Hwang, G.J., Chu, H.C., Lin, Y.S. and Tsai, C.C. (2011), “A knowledge acquisition approach to developing Mindtools for organizing and sharing differentiating knowledge in a ubiquitous learning environment", Computers and Education, Vol. 57 No. 1, pp. 1368-1377, doi: 10.1016/j. compedu.2010.12.013.

Iglesias, E. (2013), Robots in Academic Libraries: Advancements in Library Automation, Central Connecticut State University, USA, IGI Global, doi: 10.4018/978-1-4666-3938-6.

Islam, M.A. and Ikeda, M. (2014), "Convergence issues of knowledge management in digital libraries: steps towards state-of-the-art digital libraries", Vine: The Journal of Information, Vol. 44 No. 1, pp. 140-159, doi: 10.1108/VINE-05-2013-0029.

Ismail, M.A. and Kareem, S.A. (2011), "Identifying how novice researchers search, locate, choose and use web resources at the early stage of research", Malaysian Journal of Library and Information Science, Vol. 16 No. 3, pp. 67-85.

Joint, N. (2009), "The Web 2.0 challenge to libraries”, Library Review, Vol. 58 No. 3, pp. 167-175, doi: 10. $1108 / 00242530910942027$.

Kao, S.C. and $\mathrm{Wu}, \mathrm{C}$. (2012), "PIKIPDL A personalized information and knowledge integration platform for DL service”, Library Hi Tech, Vol. 30 No. 3, pp. 490-512, doi: 10.1108/ 07378831211266627.

Kapoor, K., Dwivedi, Y., Piercy, N.C., Lal, B. and Weerakkody, V. (2014), "RFID integrated systems in libraries: extending TAM model for empirically examining the use", Journal of Enterprise Information Management, Vol. 27 No. 6, pp. 731-758, doi: 10.1108/JEIM-10-2013-0079. 
Kesselman, M. (2017), "Conference report: 50th consumer electronics show", Library Hi Tech News, Vol. 34 No. 3, pp. 1-8, doi: 10.1108/LHTN-03-2017-0014.

Kim, B.K. and Kohtaro, O. (2009), "Information structured space and ambient intelligent systems for a librarian robot", The Journal of Korea Robotics Society, Vol. 4, pp. 147-154, available at: http:// www.koreascience.or.kr/article/JAKO200917161877604.

Kim, B.K., Ohara, K., Kitagaki, K., Ohba, K. and Sugawara, T. (2008), "Design of ubiquitous space for the robotic library system and its application", IFAC Proceedings Volumes, Vol. 41 No. 2, pp. 8221-8225, doi: 10.3182/20080706-5-KR-1001.01391.

Kim, B.K., Ohara, K., Kitagaki, K. and Ohba, K. (2009), "Design and control of librarian robot system in information structured environments", Journal of Robotics and Mechatronics, Vol. 21 No. 4, pp. 507-514.

Kim, K.J., Park, E. and Shyam Sundar, S. (2013), "Caregiving role in human-robot interaction: a study of the mediating effects of perceived benefit and social presence", Computers in Human Behavior, Vol. 29 No. 4, pp. 1799-1806, doi: 10.1016/j.chb.2013.02.009.

Kruk, S.R. and Krawczyk, H. (2004), "Intelligent resources search in virtual libraries", in Intelligent Information Processing and Web Mining, Advances in Soft Computing, Vol 25, Springer, Berlin, Heidelberg, pp. 439-443, doi: 10.1007/978-3-540-39985-8_49.

Kyrarini, M., Naeem, S., Wang, X. and Gräser, A. (2017), "Skill robot library: intelligent path planning framework for object manipulation”, 25th European Signal Processing Conference (EUSIPCO), Kos, 2017, pp. 2398-2402, doi: 10.23919/EUSIPCO.2017.8081640.

Lakshmikant, M. and Vishnu, S. (2008), Automation and Networking of Libraries (Electronic Source): A Manual of Library Management Software and Applications of Computer Technology in Libraries, New Age International, India.

Lam, K.T. and Chan, D.L.H. (2007), "Building an institutional repository: sharing experiences at the HKUST Library", OCLC Systems and Services: International Digital Library Perspectives, Vol. 23 No. 3, pp. 310-323, doi: 10.1108/10650750710776440.

Lancaster, F.W. and Smith, L.C. (1990), Artificial Intelligence and Expert Systems: Will They Change the Library?, 27th Clinic on Library Applications of Data Processing March 25-27, at the University of Illinois at Urbana- Champaign. From IDEALS, the Illinois Digital Environment for Access to Learning and Scholarship, available at: https://www.ideals.illinois.edu/handle/ 2142/1209.

Lancaster, F.W. (1997), Artificial Intelligence and Expert System Technologies: Prospects. Libraries for the New Millennium: Implications for Managers, Library Association, London, pp. 19-38.

Leslie, D. (1999), "Industry experts gather to map future of libraries", The Electronic Library, Vol. 17 No. 3, pp. 149-153, doi: 10.1108/02640479910329734.

Lin, W., Yueh, H.P., Wu, H.Y. and Fu, L.C. (2013), "Developing a service robot for a children's library: a design-based research approach", Journal of the Association for Information Science and Technology, Vol. 65 No. 2, pp. 290-301, doi: 10.1002/asi.22975.

Liu, G. (2011), "The application of intelligent agents in libraries: a survey", Program, Vol. 45 No. 1, pp. 78-97, doi: 10.1108/00330331111107411.

McDonnell, M. and Shiri, A. (2011), "Social search: a taxonomy of, and a user-centred approach to, social web search", Program, Vol. 45 No. 1, pp. 6-28, doi: 10.1108/00330331111107376.

Meador, J.M. and Cline, L. (1992), "Displaying and utilizing selection tools in a user-friendly electronic environment”, Library Acquisitions: Practice \& Theory, Vol. 16 No. 3, pp. 289-294.

Mehtab Alam Ansari, A. (2008), "Awareness and use of OPACs in five Delhi libraries", The Electronic Library, Vol. 26 No. 1, pp. 111-129, doi: 10.1108/02640470810851789.

Mei, Zh., Chen, Y., Jiang, M., Wu, H. and Cheng, L. (2017), "Mobile robots path planning based on dynamic movement primitives library", Control Conference (CCC), 2017 36th Chinese, 26-28 July, doi: 10.23919/ChiCC.2017.8028446.

A review: intelligent libraries 
LHT

39,2

Miglino, O., Gigliotta, O., Ponticorvo, M. and Nolfi, S. (2008), "Breedbot: an evolutionary robotics application in digital content”, The Electronic Library, Vol. 26 No. 3, pp. 363-373, doi: 10.1108/ 02640470810879509.

Mikawa, M. (2010), A Practicum Track Using Librarian Robot in Support Program for Contemporary Educational Needs, University of Tsukuba, Japan, available at: http://www.iiis.org/CDs2010/ CD2010SCI/SCI_2010/PapersPdf/SA431IB.pdf (accessed 21 June 2018).

Milella, A., Cicirelli, G. and Distante, A. (2008), "RFID-assisted mobile robot system for mapping and surveillance of indoor environments”, Industrial Robot, Vol. 35 No. 2, pp. 143-152, doi: 10.1108/ 01439910810854638.

Mishra, L. and Srivastava, V. (2008), Automation and Networking of Libraries [Electronic Resource]: A Manual of Library Management Software and Applications of Computer Technology in Libraries, New Age International.

Modler, N., Hufenbach, W., Comsa, A., Maniu, I., Zichner, M. and Friedrich, J. (2012), "Compliant structures in book handling applications", Applied Mechanics and Materials, Vol. 162, pp. 543-548.

Modler, N., Comsa, A., Maniu, I., Lovasz, E.C. and Ciupe, V. (2014), "Dedicated gripper for books handling in a library", in Visa, I. (Eds), The 11th IFToMM International Symposium on Science of Mechanisms and Machines. Mechanisms and Machine Science, Vol. 18, Springer, Cham, doi: 10.1007/978-3-319-01845-4_51.

Noh, Y. (2013), "A study on next-generation digital library using context-awareness technology", Library Hi Tech, Vol. 31 No. 2, pp. 236-253, doi: 10.1108/07378831311329031.

O'Neill, M. and Morris, A. (1989), "The contribution of library and information science to expert system development”, The Electronic Library, Vol. 7 No. 5, pp. 295-300, doi: 10.1108/eb044908.

Oyelude, A.A. (2017), "What's trending in libraries from the internet cybersphere-artificial intelligence and other emerging technologies”, Library Hi Tech News, Vol 34 No. 2, pp. 11-12, doi: 10.1108/ LHTN-02-2017-0008.

Park, E. and Kim, K.J. (2013), "User acceptance of long-term evolution (LTE) services: an application of extended technology acceptance model”, Program, Vol. 47 No. 2, pp. 188-205, doi: 10.1108/ 00330331311313762.

Park, E., Sung, J. and Cho, K. (2015), "Reading experiences influencing the acceptance of E-book devices", The Electronic Library, Vol. 33 No. 1, pp. 120-135, doi: 10.1108/EL-05-2012-0045.

Payne, G.F. and Bradbury, D. (2002), "An automated approach to online digital reference: the Open University Library OPAL Project", Program-Electronic Library and Information Systems, Vol. 36 No. 1, pp. 5-12, doi: 10.1108/00330330210426076.

Phillips, D. (2017), "Robots in the Library: gauging attitudes towards developments in robotics and ai, and the potential implications for library services”, Dissertation, University of London, doi: 10. 17613/M6535M.

Prats, M., Sanz, P.J., Del Pobil, A.P., Martínez, E. and Marín, R. (2007), "Towards multipurpose autonomous manipulation with the UJI service robot”, Robotica, Vol. 25 No. 2, pp. 245-256, doi: 10.1017/S0263574706003304.

Prats, M., Martínez, E., Sanz, P.J. and Del Pobil, A.P. (2008), "The UJI librarian robot", Intel Serv Robotics, Vol. 1 No. 4, pp. 321-335, doi: 10.1007/s11370-008-0028-1.

Ramos-Garijo, R., Prats, M., Sanz, P.J. and Del Pobil, A.P. (2003), “An autonomous assistant robot for book manipulation in a library", Paper presented at the IEEE International Conference on Systems, Man and Cybernetics, 8-8 October, USA: Washington DC, doi: 10.1109/ICSMC.2003.1244499.

Rudall, B.H. (2006), “Contemporary systems and cybernetics”, Kybernetes, Vol. 35 Nos 1/2, pp. 209-216, doi: $10.1108 / 03684920610640326$.

Sacchanand, C. and Jaroenpuntaruk, V. (2006), "Development of a web-based self-training package for information retrieval using the distance education approach”, The Electronic Library, Vol. 24 No. 4, pp. 501-516, doi: 10.1108/02640470610689197. 
Sharda, S., Delen, D., Turban, T. and King, K. (2017), Business Intelligence: A Managerial Approach, Global Edition, Pearson, available at: https:/www.pearson.com/uk/educators/highereducation-educators/product/Sharda-Business-Intelligence-A-Managerial-Approach-GlobalEdition-4th-Edition/9781292220543.html (accessed April 13, 2020).
A review: intelligent libraries

Singh, D.K., Singh, B.K. and Dubey, Y.P. (1996), "Expert systems and their application in library and information systems", DESIDOC Bulletin of Information Technology, Vol. 16 No. 4, pp. 9-12, available at: http://publications.drdo.gov.in/ojs/index.php/djlit/article/download/ 3272/1727/ (accessed 21 April 2019).

Sowell, S.L. (1989), "Expanding horizons in collection development with expert systems: development and testing of a demonstration prototype", Special Libraries, Vol. 80 No. 4, pp. 45-50.

Taha, A. (2012), "Networked library services in a research-intensive university", The Electronic Library, Vol. 30 No. 6, pp. 844-856, doi: 10.1108/02640471211282145.

Vincze, J. (2017), “Virtual reference librarians (Chatbots)”, Library Hi Tech News, Vol. 34 No. 4, pp. 5-8, doi: 10.1108/LHTN-03-2017-0016.

Waters, S.T. (1986), "Answerman, the expert information specialist - an expert system for retrieval of information from library reference-books", Information Technology and Libraries, Vol. 5 No. 3, pp. 204-212.

Weiss, P.J. (1994), "The expert cataloging assistant project at the national-library-of-medicine", Information Technology and Libraries, Vol. 13 No. 4, pp. 267-271.

Wu, H.C., Chou, C., Ke, H.R. and Wang, M.H. (2010), "College students' misunderstandings about copyright laws for digital library resources", The Electronic Library, Vol. 28 No. 2, pp. 197-209, doi: $10.1108 / 02640471011033576$.

Xiaobin, L. and Jing, G. (2009), "Innovation community: constructing a new service mode for academic libraries", The Electronic Library, Vol. 27 No. 2, pp. 258-270, doi: 10.1108/ 02640470910947601.

Yao, F., Lei, J., Chengyu, Z. and Wu, Ch. (2011), "New attempt on real-time virtual reference service: the smart chat robot of tsinghua university library", New Technology of Library and Information Service, Vol. 27 No. 4, pp. 77-81, available at: http://manu44.magtech.com.cn/Jwk_infotech_wk3/ EN/10.11925/infotech.1003-3513.2011.04.13.

Yao, F., Zhang, Ch. and Chen, W. (2015), "Smart talking robot Xiaotu: participatory library service based on artificial intelligence", Library Hi Tech, Vol. 33 No. 2, pp. 245-260, doi: 10.1108/LHT-022015-0010.

Yi, S., Bao, L. and Jianfeng, Q. (2011), "Design and implementation of library intelligent IM reference robot", New Technology of Library and Information Service, Vol. 27 No. 5, pp. 88-92, available at: http://manu44.magtech.com.cn/Jwk_infotech_wk3/EN/10.11925/infotech.1003-3513.2011.05.14.

Yuehu, W. and Yanqing, L. (2012), "An intelligent library based on the IOT and the robot technology", Library Work and Study, Vol. 3 No. 5, pp. 250-276, available at: http://en.cnki.com.cn/Article_en/ CJFDTOTAL-TSGG201203006.htm.

Zimerman, M. (2012), "Digital natives, searching behavior and the library", New Library World, Vol. 113 Nos 3/4, pp. 174-201 doi: 10.1108/03074801211218552.

\section{Further reading}

Berube, L. (2004), "Collaborative digital reference: an ask a librarian (UK) overview”, Program, doi: 10. 1108/00330330410519189?fullSc $=1$.

Clyde, L.A. (2000), “A strategic planning approach to Web site management”, The Electronic Library, Vol. 18 No. 2, pp. 97-108, doi: 10.1108/02640470010325637.

Detlor, B. and Arsenault, C. (2002), "Web information seeking and retrieval in digital library contexts: towards an intelligent agent solution", Online Information Review, Vol. 26 No. 6, pp. 404-412, doi: $10.1108 / 14684520210452736$. 
LHT 39,2

El-Sherbini, M. and Klim, G. (2004), "Metadata and cataloging practices", The Electronic Library, Vol. 22 No. 3, pp. 238-248, doi: 10.1108/02640470410541633.

MacDougall, J., Brittain, J.M. and Gann, R. (1996), "Health informatics: an overview", Journal of Documentation, Vol. 52 No. 4, pp. 421-448, doi: 10.1108/eb026974.

Mardikian, J. (1995), "Self-service charge systems: current technological applications and their implications for the future library", Reference Services Review, Vol. 23 No. 4, pp. 19-38, doi: 10. 1108/eb049262.

Morales, E.R. (1999), "Generis: the ec-jrc generalised software control system for industrial robots", Industrial Robot: International Journal, Vol. 26 No. 1, pp. 26-32, doi: 10.1108/ 01439919910250197.

Omekwu, C.O. (2006), "African culture and libraries: the information technology challenge", The Electronic Library, Vol. 24 No. 2, pp. 243-264, doi: 10.1108/02640470610649218.

Raitt, D.I. (1985), "Look-no paper! the library of tomorrow", The Electronic Library, Vol. 3 No. 4, pp. 276-289, doi: 10.1108/eb044666.

Reneker, M.H. and Buntzen, J.L. (2000), "Enterprise knowledge portals: two projects in the United States Department of the Navy", The Electronic Library, Vol. 18 No. 6, pp. 392-403, doi: 10.1108/ EUM0000000005386.

Tegenbos, J. and Nieuwenhuysen, P. (1997), "My kingdom for an agent? evaluation of autonomy, an intelligent search agent for the internet", Online and CD-Rom Review, Vol. 21 No. 3, pp. 139-148, doi: 10.1108/eb024616.

\section{Corresponding author}

Asefeh Asemi and Mohsen Nowkarizi can be coneccted at: asemi.asefeh@uni-corvinus.hu

For instructions on how to order reprints of this article, please visit our website:

www.emeraldgrouppublishing.com/licensing/reprints.htm

Or contact us for further details: permissions@emeraldinsight.com 